\title{
Effect of Naphthalene acetic acid on Biochemical parameters, Growth and Yield of Tomato (Lycopersicon esculentum Mill.)
}

\author{
${ }^{1}$ Subhash C. Pargi, ${ }^{2}$ Dr. E.P. Lal and ${ }^{3}$ Neha Singh ${ }^{4}$ Tarun K. Biswas \\ ${ }^{1,2,3,4}$ Department of Biological Sciences, Sam Higginbottom Institute of Agriculture, Technology \\ and Sciences, Allahabad, Uttar Pradesh
}

\begin{abstract}
A pot experiment was performed according to a randomized block design at Sam Higginbottom Institute of Agriculture, Technology \& Sciences, Allahabad (Uttar Pradesh) to study the effect of 5 levels of Naphthalene acetic acid spray $(10,20,30,40$ and $50 \mathrm{ppm}$ NAA) on the vegetative growth, yield and quality parameters of tomato cultivar (Lycopersicon esculentum Mill.). Irrespective of its concentration, spray of Naphthalene acetic acid proved beneficial for all parameters.
\end{abstract}

Key Words: Tomato, Lycopersicon esculentum Mill. NAA spray, ppm, growth, yield.

\section{Introduction}

Tomato (Lycopersicon esculentum L.) belonging to Solanaceae and its origin is the Andean zone particularly Tomato particularly Peru-Ecuador-Bolivian areas but cultivated tomato originated in Mexico. The production of Tomato in India is dominated by Andhra Pradesh which contributes nearly 36\% (5926.2 mt/hec) to the total production. Karnataka is the second largest producer contributing $10 \%(1756.7 \mathrm{mt} / \mathrm{hec})$ to the total production followed by Orissa $8 \%(1367.2 \mathrm{mt} / \mathrm{hec})$, West Bengal $6 \%(1063.7 \mathrm{mt} / \mathrm{hec})$, Bihar $6 \%(1056.2$ $\mathrm{mt} / \mathrm{hec})$, Gujrat 6\% (948.4 mt/hec), Maharashtra 4\% (738.0 mt/hec), Chhattisgarh 4\% $(627.9 \mathrm{mt} / \mathrm{hec})$, Tamilnadu 3\% (580.6 mt/hec), Jharkhand 2\% (401.6 mt/hec), and others $15 \% \quad(2330.8 \mathrm{mt} / \mathrm{hec})$ (Indian Horticulture Database, 2011). Tomato is one of the most highly praised vegetables consumed widely and it is a major source of vitamins and minerals. It is one of the most popular salad vegetables and is taken with great relish. It is widely employed in cannery and made into soups, conserves, pickles, ketchup, sauces, juices etc. Use of plant growth regulators is a common horticultural practice to improve yield. Plant growth regulators can affect rooting, flowering, fruiting and fruit growth, leaf or fruit abscission, senescence, regulation of some metabolic processes and plant resistance to temperature or water stresses. The plant growth regulators are known to enhance the source sink relationship and stimulate the translocation of photo assimilates thereby helping in better retention of flowers and fruits. Besides this, the growth regulators have the ability to cause accelerated growth in plant.

Naphthalene acetic acid is synthetic plant hormone in the Auxin family.it is known to stimulate cell division, cell elongation, elongation of shoot, photosynthesis, RNA synthesis membrane permeability and water uptake also involved in many physiological processes like prevention of pre harvest fruit drop, flower induction, fruit set, delayed senescence and prevention of bud sprouting, leaf chlorophyll content, and increased yield in fruit crops etc

Realizing the significance of this experiment with the objective of to study the effect of Naphthalene acetic acid on growth, quality and yield of tomato.

\section{Materials and Methods}

The experiment was carried out during Rabi season 2014, Department of Biological Sciences, SHIATS, Allahabad (U.P.). The experiment consisted one tomato variety - Golden, five levels of naphthalene acetic acid arranged in randomized block design with three replications and six treatments (T0 - Control, T1NAA@10 ppm, T2- NAA@20 ppm, T3- NAA@30 ppm, T4- NAA@40 ppm and T5- NAA@ 50 ppm). The required weight of PGRs was taken using electronic sensitive balance and solution was prepared by dissolving in $1 \mathrm{mg} \mathrm{L}^{-1}$. The solution was directly sprayed on the plants three times at 20,40 and 60 days after transplanting. Spraying was performed early in the morning to avoid rapid drying of the spray solution, due to transpiration. The collected data includes average plant height $(\mathrm{cm})$, number of leaves per plant, number of fruit per plant, fresh fruit weight $(\mathrm{kg} / \mathrm{plant})$, total chlorophyll, fruit protein content $(\mathrm{mg} / \mathrm{gm})$ and lycopene content (mg/100gm). 
3.1 Growth parameters

\section{Result and Discussion}

\subsubsection{Plant height (cm)}

\begin{tabular}{|c|c|c|c|c|c|c|}
\hline \multirow{2}{*}{ Treatments } & \multicolumn{3}{|c|}{ Plant height (cm) } & \multicolumn{3}{c|}{ Number of leaves } \\
\cline { 2 - 7 } & 20 DAT & 40 DAT & 60 DAT & 20 DAT & 40 DAT & 60 DAT \\
\hline T0 & 18.0 & 26.2 & 36.1 & 13.6 & 20.4 & 31.1 \\
\hline T1 & 19.0 & 30.6 & 42.0 & 14.6 & 24.9 & 33.2 \\
\hline T2 & 21.8 & 33.0 & 45.2 & 14.7 & 27.1 & 36.5 \\
\hline T3 & 26.9 & 38.0 & 52.1 & 15.4 & 37.3 & 46.0 \\
\hline T4 & 24.7 & 36.8 & 50.5 & 15.3 & 36.1 & 44.3 \\
\hline T5 & 27.2 & 42.3 & 60.5 & 16.6 & 43.2 & 50.1 \\
\hline
\end{tabular}

At 20 DAT maximum plant height was found in T5 (27.2) and minimum was found in (18.0), At 40 DAT maximum plant height was found in T5 (42.3) and minimum was found in (26.0). At 60 DAT maximum plant height was found in T5 (36.1) and minimum was found in (60.5), Similar result was found by Kannan $\boldsymbol{e t}$ al. (2009) in paprika.

\subsubsection{Number of leaves/plant}

At 20 DAT maximum number of leaves/plant was found in T5 (16.6) and minimum was found in (13.6), At 40 DAT maximum number of leaves/plant was found in T5 (43.2) and minimum was found in (20.4). At 60 DAT maximum number of leaves/plant was found in T5 (50.1) and minimum was found in (31.1),Similar result was found by Gabal et al. (1999) in Tomato and Kannan et al. (2009) in paprika

\subsection{Biochemical parameters}

\subsubsection{Total Chlorophyll (mg/gm)}

At 60 DAT maximum chlorophyll was found in T5 (5.69) and minimum was found in (3.80), Similar result was found by Chandra and Shivraj (1972) in chilli and Chandal et al. (2004) rice and mustard and Hemantaranjan et al. (2000) in soybean in also significant.

\subsection{Quality Parameters}

\subsubsection{Protein content $(\mathrm{mg} / \mathrm{gm})$}

At 60 DAT maximum protein content was found in T5 (2.3) and minimum was found in (0.9). Similar result was found by Ghanem et al., (2008).

\subsubsection{Lycopene (mg/100gm)}

At 60 DAT maximum lycopene was found in T5 (3.8) and minimum was found in (2.0)' Similar result was found by Chang and Liu ., (2008)

\subsection{Yield Parameters}

\subsubsection{Number of fruits/ plant}

At 60 DAT maximum number of fruit per plant was found in T5 (19.1) and minimum was found in (9.0), Similar result was found by Khuarana et al. (2004) and Choudhary et al. (2006).

\subsubsection{Fruits weight (kg/plant)}

At 60 DAT maximum fruit weight was found in T5 (1.5) and minimum was found in (0.9),Similar result was found by Gelmesa et al. (2010) in tomato. Sumiati (1987) and Edison (1991) in tomato and Chandra and Shivraj (1972) in chilli.

Table 1. Effect of NAA on vegetative growth parameters.

Table 2. Effect of NAA on quality parameters.

\begin{tabular}{|c|c|c|c|c|c|}
\hline & $\begin{array}{c}\text { Number of fruits/ } \\
\text { plant }\end{array}$ & $\begin{array}{c}\text { Fruits weight } \\
\text { (kg/plant) }\end{array}$ & $\begin{array}{l}\text { Chlorophyll } \\
\text { (mg/gm) }\end{array}$ & $\begin{array}{l}\text { Protein content } \\
(\mathrm{mg} / \mathrm{gm})\end{array}$ & $\begin{array}{l}\text { Lycopene } \\
\text { (mg/100gm) }\end{array}$ \\
\hline Treatments & 40 DAT & 60 DAT & 60 DAT & 60 DAT & 60 DAT \\
\hline $\mathbf{T}_{0}$ & 9.0 & 0.9 & 3.80 & 0.9 & 2.0 \\
\hline$T_{1}$ & 12.2 & 1.1 & 4.52 & 1.7 & 2.2 \\
\hline$T_{2}$ & 15.0 & 1.2 & 4.74 & 2.0 & 2.5 \\
\hline $\mathbf{T}_{3}$ & 16.0 & 1.3 & 5.10 & 2.3 & 3.2 \\
\hline $\mathbf{T}_{4}$ & 16.0 & 1.3 & 5.47 & 2.2 & 3.4 \\
\hline $\mathbf{T}_{5}$ & 19.1 & 1.5 & 5.69 & 2.3 & 3.8 \\
\hline
\end{tabular}




\section{Conclusion}

Based on the results, it can be concluded that, Naphthalene acetic acid had significant influence on growth, quality and yield of tomato, especially the treatment with the application of NAA @ 50 ppm and NAA (a) 30 ppm.

\section{Reference}

[1]. Chang C.H. and Liu Y.C., (2008) Evaluation of the antioxidative performance of tomato extracts obtained by different methods. J. Sci. Food Agric., 88: 612-618.

[2]. Chandal R.S., Kalyan and Singh R., (2004) Effect on sulphur application on quality of rice and mustard growth in sequence. New Agri., 11 (1-2):1-7.

[3]. Chandra R. and Shivraj A., (1972) Influence of exogenous hormones on flowering, flower shedding and fruits set of chilli (Capsicum annuum L.). Andhra agric. J., 19(1\&2): 34-44.

[4]. Chaudhary B.R., Sharma M.D., Shakya S.M. and Gautama D.M., (2006) Effect of plant growth regulators on growth, yield and quality of chilli (Capsicum annuum L.) at rampur, chitwan. J Inst. Agric. Anim.sci. 27:65-68.

[5]. Gabal G.M., Oben G. and Garcell R., (1999)Effect of GA on morph physiological characters and yield of kidney beans (Phaseiolus valgaris). J. Agron. Crop. Sci., 160(2): 91-101

[6]. Ghanem et al., (2008). Hormonal changes during salinity-induced leaf senescence in tomato (Solanum lycopersicum L.). J Exptl Bot 59, 3039-3050.

[7]. Hemantaranjan A., Trivedi A.K. and Mauiram S., (2000) Effect of foliar applied boron and soil applied phosphorus and sulphur on growth, yield and chlorophyll content of soybean. Indian J. of Plant Physio, 5(2): 142-149.

[8]. Kannan K., Jawaharlal M. and Prabhu M., (2009) Effect of plant growth regulators on growth and yield parameters cv.KtP1-19. Agric. Sci. Digest, 29 (3): 157-162.

[9]. Khurana D.S., Manchanda D., Singh J. and Singh Kulbir., (2004) Influence of Naphalene acetic acid on growth and fruit yield of chilli. Haryana J. Hort. Sci., 33(3/4):274-275.

[10]. Sumiati, E., (1987) Effect of plant growth regulators on flowering and yield of tomatoes in the Lembang Highlands. Bull. Pene. Hortic. 15 (1): 134-143. 